\title{
MULTIPLE NASH EQUILIBRIUMS AND EVALUATION OF STRATEGIES. NEW APPLICATION OF MCDM METHODS
}

\author{
Sarfaraz HASHEMKHANI ZOLFANI ${ }^{1}$, Reza MAKNOON ${ }^{2}$, \\ Edmundas Kazimieras ZAVADSKAS ${ }^{3}$
}

${ }^{1,2}$ Technology Foresight Group, Department of Management, Science and Technology, Amirkabir University of Technology (Tehran Polytechnic), P.O. Box 1585-4413, Tehran, Iran

${ }^{3}$ Research Institute of Smart Building Technologies, Vilnius Gediminas

Technical University, Sauletekio al. 11, LT-10223 Vilnius, Lithuania

${ }^{1}$ sa.hashemkhani@gmail.com; ${ }^{2}$ maknoon@aut.ac.ir;

3edmundas.zavadskas@vgtu.lt (correspondingauthor)

Received 30 June 2014; accepted 17 September 2014

\begin{abstract}
There are two different approaches in this study with different implications. The first approach and the main aim of this study is a methodological framework. There are different frameworks in solving game theory topics involving at least two Nash Equilibriums. This study presents a new framework for developing this part of game theory with MCDM framework. The authors believe that at least there is a perspective or paradigm behind each game theory topic, leading to the development of strategies accordingly. For this purpose a hybrid MCDM method based on SWARA-WASPAS is applied in the process of research for evaluating the strategies. The general topic of this research is in supply chain management field. This research also focuses on this issue and implies extend of the complication involved. An additional focus in the present paper is on defining a game. This research addresses developing strategies from only stable strategies to both normal and dynamic strategies. The topic is established to find the best mixed strategy considering current international and economical position of Iran against complicated international relations' issues and specially sanction.
\end{abstract}

Keywords: game theory, Nash Equilibrium, MCDM, SWARA, WASPAS, supply chain management, strategy evaluation.

JEL Classification: C44, C68, C90, M11, L11.

\section{Introduction}

This study isn't only a classical research based on game theory and MCDM methods. Game theory and MCDM framework are the multi-disciplinary approaches to solve the problems and make decisions, classically under these approaches a normal or a stable situation and environment may be considered.

Making decision in critical and complicated topics needs a more flexible approach. This research is organized to illustrate a new flexible dynamic decision regarding tough issues. This research is focused on a supply chain management (SCM) topic. 
The research will start with a classic game theory model. Although the model of game theory is unique in this research, the approach is normal and stable. The model of this research is based on a new approach. There is a new perspective to make a more flexible strategy for selecting the best alternative as a supplier. More information will be ready in sections 5 and 6 .

The main contribution will start from this step. When there are at least two Nash Equilibriums, what do researchers do? The answer is easy; there is more than a single answer for a topic. As everyone knows there is always a goal, perspective or paradigm behind a game theory issue. Now, the big question is: why the decision makers did not evaluate Nash Equilibriums? This study presents an approach for this notion based on MCDM framework.

Another important part of this study is applying a hybrid MCDM method based on SWARA-WASPAS. This hybrid methodology is applied for evaluating the criteria and mixed strategies (Nash Equilibriums). Consequently, strategy evaluation based on MCDM methodology was considered for decision making when there are more than two Nash Equilibriums. The importance of this new framework can be more useful in decision and policy making.

The rest of the research starting from literature review includes: game theory, MCDM, supply chain management (SCM); methodology; case study; describing strategies; experts information; results and finally conclusion.

\section{Literature review}

In this section a brief review of game theory and MCDM is presented in separate sections. The history of these two fields can be seen in the following sections.

\subsection{Game theory}

Different means are available to approach strategic conflicts (Li et al. 2004), such as metagame analysis (Howard 1971), hypergame analysis (Bennett 1980; Wang et al. 1988), conflict analysis (Fraser, Hipel 1984), the Graph model for conflict resolution (GMCR) (Kilgour et al. 1987; Fang et al. 1993), drama theory (Howard 1999), and the theory of moves (Brams 1994), all with the same game-theoretic origin (Kilgour 1995). A strategic game has different constituents, set of players, strategies for each player and the reward for each strategy combination. The strategy defines the particular way a player has to act under certain circumstances (Banerjee et al. 2006; Soner Aplak, Ziya Sogut 2013). Game theory has been applied to many realms such as economics, political science and psychology, logic and biology (Nash 1950; 1953; Gibbons 1991; Li et al. 2013).

By game theory the mathematical theory of interactive decision situations is made possible (Mohammadi Limaei 2010). To clarify strategies that individuals must adopt when competing or co-operating in games (Binmore 1994), game theory presents helpful mathematical tools. Social sciences (mainly economics), biology, engineering, political science, international relations, computer science and philosophy (Burguillo 2010) 
have been the areas to which this branch of applied mathematics can be used. In every situation agents make decisions and based upon them the certain results will emerge, accordingly each agent has his/her way of dealing with the possible outcomes (FiestrasJaneiro et al. 2011). The purpose of game theory is to model situations in which many participants, whose interactions affect each other's outcomes, take part (Nisan et al. 2007). Interactive behavior of decision-making and interests in situations in which a DM's behavior affects not only their own profits or losses but also those of opposing DMs, will be studied. Game theory doesn't necessarily mean obtaining an otherwise unavailable problem solution but rather urges strategic thinking targeted at resolving the decision problem. As an example, the game theory formulation adds time to the decision process (Reneke 2009).

It is proven that game theory is an asset in the modeling and analysis of many phenomena including interaction between multiple agents (Rego, Halpern 2012).

The salient elements of a game include (1) the players, (2) the strategies or preferences they adopt, (3) the information at hand, (4) the order of play, and (5) the outcome or payoff of the game, which is influenced by the previous four factors. A game has at least two players who make decisions; these players can be individuals, communities, corporations, or the government. Every player has his/her own preference and strategy that means "a complete plan of action that describes what a player will do under all possible circumstances" (Davis 1997; Law, Pan 2009).

It is important to clarify the territory between the game and the game theory trying to understand the research point of view. Taxonomies of strategic situations are called games but a mathematical derivation analyzing the cognitive abilities of player's strategies is known to be game theory (Camerer 2003; Sharma, Bhattacharya 2013).

Game theory issues are often multi-criteria multi-decision-maker problems. In order to solve such problems by conventional optimization methods, normally the problem is changed completely to a single-decision maker problem with a single composite objective for the whole system such as an overall economic or social welfare function or a weighted constrained multi-objective function (Madani 2010). Since the seminal book by John von Neumann and Oskar Morgenstern (1944) "Theory of Games and Economic Behavior", it is very much common to divide game theory into two main groups of interaction situations (which are called games), i.e. non-cooperative and cooperative games. Non-cooperative games study situations in which players find it hard to reach an agreement over a conflict. Meanwhile in cooperative games there is a possibility of all types of agreement among the players (Moretti, Vasilakos 2010). In non-cooperative games each player tends to behave in his own interest taking into consideration that the outcome of a game has to do with the actions of all the players involved. Actions by players can take place at the same time (the 'stone, paper, scissors' game or the 'matching pennies' game) or at several time points (chess, backgammon) (Moretti, Vasilakos 2010). The main application of matrix games is the selection of variants, which is a problem of multi-criteria decisions (Peldschus 2007, 2008; Meszek 2001, 2004, 2007, 2013; Zagorskas, Turskis 2006; Kaplinski, Tamosaitiene 2010). 


\subsection{Multiple-criteria decision making (MCDM)}

The traditional MCDM provides us with options to select the best solution. Nonetheless, Simon, who won the Nobel Prize in economics in 1978, asserts that decision making does not necessarily follow the basic tenets of the "rational man". Humans do not solve problems through maximizing utility, but are "satisfiers" who set aspiration levels that a solution must satisfy. If humans can identify a solution that satisfies the stated aspiration levels, they accept the solution (Liou, Tzeng 2012).

With the development of MCDM, the focus has been diverted from ranking and selecting alternatives to improving their performance. The old models can only help us to identify the gaps between competing alternatives (Liou, Tzeng 2012). Multiple-criteria decision making (MCDM), commonly known as multi criteria decision aid (MCDA) and multi-criteria analysis (MCA), is a set of methods in which the aggregation and consideration of numerous (often conflicting) criteria to choose, rank, sort or describe a set of alternatives to aid a decision process is allowed (Zopounidis 1999; Mulliner et al. 2013). Multi-criteria analysis is quiet helpful to determine the best solution among several options based upon multiple-attributes or criteria (Chang, Hsu 2009). The purpose of MCDA is to support decision makers, who encounter numerous and conflicting choices (Lootsma 1999; Barfod et al. (2011). The Multiple-criteria decision making (MCDM) approach is taken to assess advantages and disadvantages of options on the basis of multiple-criteria especially when there is a variety of options with multiple, potential conflicting dimensions which cannot be evaluated by the measurement of a simple, single dimension (Vreeker et al. 2002; Postorino, Pratico 2012).

All MCDM techniques that have three steps are mentioned here (Triantaphyllou 2000; Hyde, Maier 2006):

1. Determining pertinent criteria and alternatives;

2. Attaching numerical measures to the relative importance of the criteria and to the impacts of the alternative on these criteria;

3. Process the numerical values to determine a ranking of each alternative.

\subsection{Supply chain management (SCM)}

Some different enterprises sharing common information and logistic networks are taken into account by the supply chains. Because of distributed nature of the system and the decisional autonomy of heterogeneous decision centers, ordering the tasks and activities raises certain problems of coordination and integration (Hennet, Arda 2008).

The main tenets of those chains are that the firms in the chain are independent actors who seek to optimize their individual objectives, and that the decisions taken by a firm can also have effects on the performance of the other parties in the supply chain. Alignment and coordination of actions are needed in order for these interactions among firms' decisions to happen, hence, game theory is the proper method to handle these interactions (Fiestras-Janeiro et al. 2011).

Because of the corporate structure and the market globalization in the recent years, industries have to become more competitive, and try to achieve more benefits, reduce 
losses; they also need to improve the quality of services and products, etc. But we shouldn't underestimate the fact that the efficiency of a company may be hampered by the efficiency of its supply chain management procedures (Zamarripa et al. 2012). Currently there are many research groups working on developing of systematic methods to improve decision making at its different hierarchical levels; these methods include the tactical decision level which has proven to be one of the most important for the day-to-day SC optimization (Zamarripa et al. 2013). Also Zamarripa et al. (2013) presented a framework from applications of game theory in SC. The framework is shown in Figure 1.

In this section a case is presented as an example to illustrate methodology of this research. Consider a special situation like Iran's position in the world. A problem like sanctions against Iran has many outcomes. Many companies and organizations nearly bankrupted and eventually Iran has suffered greatly from economic problems. There are two approaches for Iranian companies to select their suppliers. Companies have seen what happens if some problems such as sanctions take place. There are two players for this research. The first one is a good foreign supplier company and the other one is a good internal supplier company.

This research is organized generally and considers the general position of companies and their situations. The main focus of this research is on methodology and strategies selection and evaluation. In the next steps there shall be the significant point of showing differences in decision making from different aspects, paradigms and situations. The case is based on general visions and international position of Iran presented by the Iranian government. This research will apply game theory and MCDM framework dynamically.

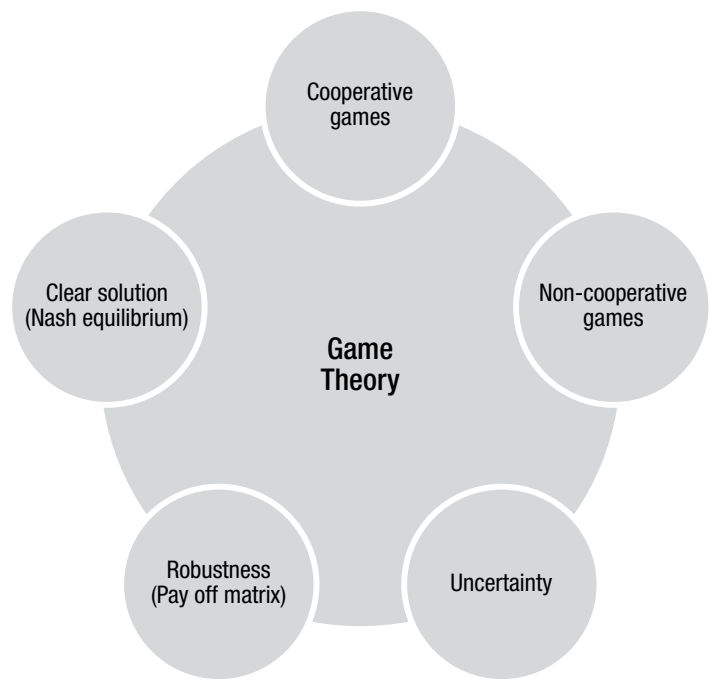

Fig. 1. Use of the game theory as a tool to manage SC under uncertainty (Zamarripa et al. 2012) 
As mentioned before, in special situations, MCDM methods can be helpful in the decision making process with game theory. If an issue has more than one similar Nash Equilibrium, this developed methodology can be useful. In real cases, the events of a similar nature are numerous, but supply chain management is an important issue in Iran. One of the critical issues in the terrible inflation in Iran is SCM topic.

In the next step, at first strategies will be presented and followed by the game theory model.

\section{Methodology}

Any situation in which people or animals interact is called a game; and strategies are the plans of action of the players. Any profile of strategies - one for each player - in which each player's strategy is a best reaction to the strategies of the other players is called Nash equilibrium.

Nash equilibrium in game theory is a solution concept of a game including two or more players, in which each player is assumed to know the equilibrium strategies of the other players, and no player has anything to gain by changing only his or her own strategy unilaterally (Nash, 1950; Mohammadi Limaei 2010). The outcome of the strategic interaction of several decision makers can be put under analysis by the Nash equilibrium concept.

Why Nash equilibrium has to be this much important? At least two reasons can be mentioned. First, if a game has a rational solution that is known to all the players, then it must be equilibrium. Rationally speaking, players have to play optimally even if some of the players would have to believe that it is rational for them not to make their best reply to what they know the other players are going to do. The second reason is more important. If the payoffs are to be in proportion to how fit the players are then evolutionary processes - either cultural or biological - the more fit players will be selected and the evolutionary process dispenses with the weak ones (Mohammadi Limaei 2010).

This research is aimed at answering the question: when in an issue there is more than one NE and both of them are the same, which one is better? Which strategy is more important? What should be the process of decision making?

The intersection of game theory and MCDM is here. Paradigms, political and social priority, regulation and some other issues are effective in the process of decision making. But game theory can't respond to all aspects of needs. MCDM can be applied in this part to evaluate strategies. MCDM methods can direct an issue to goals. Each model can be evaluation based on MCDM methodology and results can be more helpful and practical. But this research is focused only on those topics in which there are at least two Nash Equilibriums and the study is based on strategies evaluation of Nash equilibriums.

In this research, important criteria are presented as a model for evaluating strategies, then two MCDM methods are applied for evaluating strategies and criteria. At the first step SWARA method is applied for evaluating criteria and model of research. SWARA weighted all criteria and then WASPAS method is used for evaluating strategies. The 
output of this research is selection of one strategy among others. As a matter of fact this new hybrid methodology can select the best Nash Equilibriums for the decision maker. Again it should be borne in mind that this new hybrid model is useful in cases where there is more than one similar Nash Equilibrium.

\subsection{Step-wise weight assessment ratio analysis (SWARA) method}

SWARA method, a new brand MADM method, can be used instead of AHP, ANP and FARE methods. SWARA is introduced by Kersuliene et al. (2010) and developed significantly in recent years. SWARA can be called an expert-oriented method for the experts' opinions have the considerable importance role in evaluations and calculating weights in the process of this method. For the next step, experts evaluate the value of each criterion and rank all the criteria from the first to the last one. After that the importance of each criterion is calculated and all the criteria are ranked from the first to the last one (from the most significant to the least significant); experts' implicit knowledge information and experiences will be the benchmark. The overall ranks of the group of experts are chosen based on the mediocre value of ranks (Kersuliene, Turskis 2011). One of the effective and powerful attributes of SWARA method is its ability to estimate experts' point of view on importance ratio of the criteria in the process of their weight determination (Kersuliene et al. 2010). In order for experts to collect and organize data SWARA can also be helpful. The simplicity of the mentioned process allows the experts to work together easily (Hashemkhani Zolfani, Zavadskas 2013).

Priorities can be set with respect to companies or countries' policies without any need to evaluate and rank the criteria which is one of the other salient attributes of SWARA method that is different from other methods such as AHP and ANP.

Due to the fact that the latter will be affected by experts' evaluations priorities and the ranks, the model is created based on criteria. In conclusion, SWARA, based upon this analysis, is a useful method and is recommended to be applied in certain environments of decision making (Hashemkhani Zolfani, Zavadskas 2013). The all past and recent researches with SWARA methodology are presented below:

Hashemkhani Zolfani et al. (2013a) in product design; Hashemkhani Zolfani et al. (2013b) in investigating on the success factors of online games based on explorer; Hashemkhani Zolfani, Zavadskas (2013) in sustainable development of rural areas' building structures based on local climate; Hashemkhani Zolfani, Saparauskas (2013) in prioritizing sustainability assessment indicators of energy system; Alimardani et al. 2013 in agile supplier selection; Hashemkhani Zolfani, Seyed Agha Banihashemi (2014) in personnel selection and Hashemkhani Zolfani, Bahrami (2014) in investment prioritizing in high-tech industries.

\subsection{Weighted aggregates sum product assessment (WASPAS)}

This recently presented method is known as one of the newest methods proposed by Scientifics. This new methodology hinges on Weighted Sum Model (WSM) and Weighted Product Model (WPM). Zavadskas et al. (2012) are the innovators of this new method and they have proven the better accuracy of these aggregated methods in comparison to the accuracy of one of them. 
WASPAS calculation is based on these steps:

2.2.1. Normalized decision making matrix based on:

$$
\bar{x}_{i j}=\frac{x_{i j}}{\underset{i}{\operatorname{opt} x_{i j}}}, \text { where } i=\overline{1, m} ; j=\overline{1, n},
$$

if opt value is max;

if opt value is $\min$.

$$
\bar{x}_{i j}=\frac{{ }_{i}^{\text {opt }} x_{i j}}{x_{i j}}, \text { where } i=\overline{1, m} ; j=\overline{1, n}
$$

2.2.2. Calculating WASPAS weighted and normalized decision making matrix for summarizing part:

$$
\overline{\bar{x}}_{i j, \mathrm{sum}}=\bar{x}_{i j} q_{j}, \text { where } i=\overline{1, m} ; j=\overline{1, n} .
$$

2.2.3. Calculating WASPAS weighted and normalized decision making matrix for multiplication part:

$$
\overline{\bar{x}}_{i j, \text { mult }}=\bar{x}_{i j}^{q_{j}}, \text { where } i=\overline{1, m} ; j=\overline{1, n} \text {. }
$$

2.2.4. Final calculating for evaluating and prioritizing alternatives based on:

$$
\mathrm{WPS}_{i}=0.5 \sum_{j=1}^{n} \overline{\bar{x}}_{i j}+0.5 \sum_{j=1}^{n} \overline{\bar{x}}_{i j} \text {, where } i=\overline{1, m} ; j=\overline{1, n} \text {. }
$$

The all researchers who have used the WASPAS method up to now are described in several sources:

Hashemkhani Zolfani et al. (2013c) decision making on business issues with foresight perspective; Dejus, Antucheviciene (2013) assessment of health and safety solutions at a construction site; and Vafaeipour et al. (2014) in assessment of regions priority for implementation of solar plants.

\section{Describing strategies}

Beske et al. (2014) present two different frameworks for evaluating suppliers. The first one is belonging to normal situation and current situation and the other one is about dynamic collaborations.

The criteria (strategies) of the first framework (Normal situation) are: Orientation $\left(\mathrm{S}_{1-1}\right)$ (dedication to $\mathrm{SCM}$ ), Supply chain continuity $\left(\mathrm{S}_{1-2}\right)$, Collaboration level $\left(\mathrm{S}_{1-3}\right)$, Risk management $\left(\mathrm{S}_{1-4}\right)$, and Pro-activity $\left(\mathrm{S}_{1-5}\right)$.

The criteria (strategies) of the second framework (Dynamic collaboration) are: Knowledge assessment $\left(\mathrm{S}_{2-1}\right)$, Partner development $\left(\mathrm{S}_{2-2}\right)$, Supply chain re-conceptualization $\left(\mathrm{S}_{2-3}\right)$, Co-evolving $\left(\mathrm{S}_{2-4}\right)$, and Reflexive control $\left(\mathrm{S}_{2-5}\right)$.

Generally these frameworks are suitable considering Iran's situation in international cooperation. International cooperation is such a complicated issue for Iran because most part of industries in Iran is still related to government. Iran also isn't a member of World 
Trade Organization (WTO) and sanctions made a tough situation for all companies and industries. Today working with international partners as a part of supply chain management is full of threats. This methodology will be a good solution for making decision in this tough issue.

The game theory model of this research is presented in Table 1 based on experts' ideas. The main point of this model is to find the best strategy for evaluating suppliers with both normal and dynamic perspectives in different strategies. Companies in Iran should find the suppliers which are powerful in both dynamic and normal situations. It means this model can help decision makers to make decisions if some strategies are more important than the others. In fact this new methodology can help decision makers to make decision with account of all important perspectives, issues and criteria based on complicated situations.

As the model shows, four important strategies are involved in this research as the effective strategies in making an appropriate mixed strategy. The three Nash Equilibriums in this research are: $\left(\mathrm{S}_{1-4}-\mathrm{S}_{2-3}, \mathrm{~S}_{1-3}-\mathrm{S}_{2-4}, \mathrm{~S}_{1-4}-\mathrm{S}_{2-4}\right)$.

In the traditional models of game theory, this research is conducted and the results will be three Nash Equilibriums. But the present research is focused on some issues after this situation. Always there are general concepts about issues. Which Nash Equilibrium will be better for us? Which Nash Equilibrium will be the best due to our policies and attitudes? This research will answer these questions.

Table 1. Game theory model of research

\begin{tabular}{cccccc}
\hline $\mathrm{S}_{1} \backslash \mathrm{S}_{2}$ & $\mathrm{~S}_{2-1}$ & $\mathrm{~S}_{2-2}$ & $\mathrm{~S}_{2-3}$ & $\mathrm{~S}_{2-4}$ & $\mathrm{~S}_{2-5}$ \\
\hline $\mathrm{S}_{1-1}$ & 6.4 & 6.5 & 6.8 & 6.8 & 6.7 \\
\hline $\mathrm{S}_{1-2}$ & 7.5 & 7.4 & 7.5 & 7.7 & 7.5 \\
\hline $\mathrm{S}_{1-3}$ & 7.4 & 7.6 & 7.6 & 7.8 & 7.7 \\
\hline $\mathrm{S}_{1-4}$ & 7.6 & 7.5 & $\mathbf{7 . 8}$ & $\mathbf{7 . 8}$ & 7.6 \\
\hline $\mathrm{S}_{1-5}$ & 6.5 & 6.6 & 6.7 & 6.7 & 6.5 \\
\hline
\end{tabular}

\section{Important criteria}

This part is organized only for illustrating the important criteria for evaluating the strategies (NEs). These criteria are absolutely important merely due to Iran's situation. The first criterion surely is empowerment level $\left(\mathrm{C}_{1}\right)$. In the last century Iran always tried to have more progress in industry and technology. Undoubtedly, the cooperation with suppliers should happen in this field.

The second criterion is the level of supplying risk $\left(\mathrm{C}_{2}\right)$. How is it possible to reduce the risk? Which strategy is more suitable?

The third criterion is the strategic relation $\left(\mathrm{C}_{3}\right)$ among companies and countries. Undoubtedly, political and strategic relation between countries is very important. 
The fourth criterion will be future opportunities $\left(\mathrm{C}_{4}\right)$. The dimensions of these opportunities are future cooperation in a new market, new developments, etc.

\section{Experts' information}

Two groups of experts participated in this study. A group for the game theory section and analyses of that and another group for MCDM section (SWARA-WASPAS). The information about experts is presented in their section.

\section{Game theory section}

Five experts participated in this part. Four academic researchers in the field of supply chain management (SCM) and an academic researcher in the field of game theory have cooperated with the authors. They defined the values for game theory model from the worst to best from 1-9.

\section{MCDM section}

Four researchers of SCM field cooperated with the authors again. Two researchers in the public policy and a researcher in the futures studies joined the previous researchers in the previous section. They worked together to prioritize the criteria and weight them as well as find the alternatives being four Nash equilibriums.

\section{Results}

This section is organized for the strategies evaluation. There are four Nash equilibriums but which one can be preferred? This is the question that this section will answer. Two MCDM methods are applied in this section. After identifying the important criteria for evaluating the strategies, SWARA method is applied for evaluating the criteria and calculating the relative importance of them. In the next step WASPAS method is applied for evaluating and selecting the best Nash equilibrium of this research.

\subsection{SWARA methods' results}

As mentioned before, SWARA method is applied for weighting and evaluating the criteria in the strategies evaluation phase. There are four important criteria and in this step, based on SWARA method's general framework, the criteria are evaluated. As the experts' evaluation level of supplying risk is the most significant and strategic relation, empowerment level and future opportunities are of secondary importance. Also the weight of each criterion is specified in Table 2.

Table 2. Final results of SWARA method in weighting all strategies

\begin{tabular}{ccccc}
\hline Criterion & $\begin{array}{c}\text { Comparative } \\
\text { importance of } \\
\text { average value } s_{j}\end{array}$ & $\begin{array}{c}\text { Coefficient } \\
k_{j}=s_{j}+1\end{array}$ & $\begin{array}{c}\text { Recalculated weigh } \\
w_{j}=\frac{x_{j-1}}{k_{j}}\end{array}$ & $\begin{array}{c}\text { Weight } \\
q_{j}=\frac{w_{j}}{\sum w_{j}}\end{array}$ \\
\hline $\mathrm{C}_{2}$ & & 1 & 1.0000 & 0.3094 \\
\hline $\mathrm{C}_{3}$ & 0.1571 & 1.1571 & 0.8642 & 0.2674 \\
\hline $\mathrm{C}_{1}$ & 0.1741 & 1.1741 & 0.7361 & 0.2277 \\
\hline $\mathrm{C}_{4}$ & 0.1643 & 1.1643 & 0.6322 & 0.1956 \\
\hline
\end{tabular}




\subsection{WASPAS methods' results}

This section is organized based on the results of SWARA method section. Three mixed strategies are evaluated in this section. WASPAS methodology is applied in this section for the final evaluation of strategies. Final decision making is done based on WASPAS methodology. The process of calculating WASPAS is shown in Tables 3-7.

Decision making matrix is established based on the experts' opinions. The average of their evaluation is considered in this study. Moreover, all criteria are considered as qualitative criteria.

Table 3. Decision making matrix

\begin{tabular}{ccccc}
\hline & $\mathrm{C}_{1}$ & $\mathrm{C}_{2}$ & $\mathrm{C}_{3}$ & $\mathrm{C}_{4}$ \\
\hline Weight & 0.2277 & 0.3094 & 0.2674 & 0.1956 \\
\hline Max/Min & Max & Min & Max & Max \\
\hline $\mathrm{S}_{1-3}-\mathrm{S}_{2-4}$ & 7.000 & 6.143 & 6.857 & 6.143 \\
\hline $\mathrm{S}_{1-4}-\mathrm{S}_{2-3}$ & 6.143 & 5.286 & 6.286 & 7.000 \\
\hline $\mathrm{S}_{1-4}-\mathrm{S}_{2-4}$ & 6.286 & 6.571 & 6.857 & 6.143 \\
\hline
\end{tabular}

Table 4. Normalized decision making matrix

\begin{tabular}{ccccc}
\hline & $\mathrm{C}_{1}$ & $\mathrm{C}_{2}$ & $\mathrm{C}_{3}$ & $\mathrm{C}_{4}$ \\
\hline Weight & 0.2277 & 0.3094 & 0.2674 & 0.1956 \\
\hline Max/Min & Max & Min & Max & Max \\
\hline $\mathrm{S}_{1-3}-\mathrm{S}_{2-4}$ & 1.000 & 0.860 & 1.000 & 0.878 \\
\hline $\mathrm{S}_{1-4}-\mathrm{S}_{2-3}$ & 0.878 & 1.000 & 0.917 & 1.000 \\
\hline $\mathrm{S}_{1-4}-\mathrm{S}_{2-4}$ & 0.898 & 0.804 & 1.000 & 0.878 \\
\hline
\end{tabular}

Table 5. Weighted and normalized decision making matrix for summarizing part

\begin{tabular}{ccccc}
\hline & $\mathrm{C}_{1}$ & $\mathrm{C}_{2}$ & $\mathrm{C}_{3}$ & $\mathrm{C}_{4}$ \\
\hline Max/Min & Max & Min & Max & Max \\
\hline $\mathrm{S}_{1-3}-\mathrm{S}_{2-4}$ & 0.228 & 0.266 & 0.267 & 0.172 \\
\hline $\mathrm{S}_{1-4}-\mathrm{S}_{2-3}$ & 0.200 & 0.309 & 0.245 & 0.196 \\
\hline $\mathrm{S}_{1-4}-\mathrm{S}_{2-4}$ & 0.204 & 0.249 & 0.267 & 0.172 \\
\hline
\end{tabular}

Table 6. Weighted and normalized decision making matrix for multiplication part

\begin{tabular}{ccccc}
\hline & $\mathrm{C}_{1}$ & $\mathrm{C}_{2}$ & $\mathrm{C}_{3}$ & $\mathrm{C}_{4}$ \\
\hline Max/Min & Max & Min & Max & Max \\
\hline $\mathrm{S}_{1-3}-\mathrm{S}_{2-4}$ & 1.000 & 0.955 & 1.000 & 0.975 \\
\hline $\mathrm{S}_{1-4}-\mathrm{S}_{2-3}$ & 0.971 & 1.000 & 0.977 & 1.000 \\
\hline $\mathrm{S}_{1-4}-\mathrm{S}_{2-4}$ & 0.976 & 0.935 & 1.000 & 0.975 \\
\hline
\end{tabular}


Table 7. Final results of evaluating based on WASPAS methodology

\begin{tabular}{ccccc}
\hline & $0.5 \sum_{J=1}^{N} \overline{\bar{x}}_{i j}$ & $0.5 \prod_{j=1}^{n} \overline{\bar{x}}_{i j}$ & WSP $_{i}$ & Ranking \\
\hline $\mathrm{S}_{1-3}-\mathrm{S}_{2-4}$ & 0.4665 & 0.4652 & 0.9317 & 2 \\
\hline $\mathrm{S}_{1-4}-\mathrm{S}_{2-3}$ & 0.4750 & 0.4742 & 0.9492 & 1 \\
\hline $\mathrm{S}_{1-4}-\mathrm{S}_{2-4}$ & 0.4462 & 0.4446 & 0.8908 & 3 \\
\hline
\end{tabular}

According to the results of WASPAS methodology for evaluating the mixed strategies, $\mathrm{S}_{1-3}-\mathrm{S}_{2-4}$ is the best mixed strategy for this research in supplier cooperation strategies. This result can be considered as a core in suppliers' evaluation and selection.

This is a new perspective in the process of selecting the suppliers. This new framework considers many aspects of importance in a package. The real environment of decision making is really complicated and decision makers should consider all aspects in their decisions.

\section{Conclusions}

There were two main aims of this research. The first one was about developing game theory with MCDM framework in a special situation. The second one was about solving complexity of decision making in the process of supplier evaluation and selection.

Within a scope of unique methodological framework, authors look deeper to the Nash Equilibrium concept. When there will be at least two similar Nash Equilibriums answers for an issue, what are able to do the decision makers?

Always there is at least a perspective or paradigm behind each game theory topic. There is the available option of evaluating the perspective much better. MCDM framework can be helpful when evaluating the Nash Equilibriums. There is a different but related research that can be considered in the study as a sub-part of the study. As an application of MCDM framework, a new hybrid methodology (SWARA-WASPAS) presented by Hashemkhani Zolfani et al. (2013c) is applied in this research. In this research relative importance and weight is considered for strategies. Strategies' weights made difference and decision makers could make decision easily about Nash Equilibriums points.

Making decisions with class frameworks like MCDM or even game theory is incomplete. Classic frameworks usually consider only very limited aspects and situations. It is possible only to analyze stable environments and limited situations. It is possible to consider many different aspects under this methodology. Different classic frameworks with a related string among them constitute the total idea of this research.

One of the critical and complicated issues in the real world decision making regards supplier selection and evaluation. This topic was selected for this research to illustrate the ability and capacity of this new framework. This topic is organized based on general position of Iran in the international relations and also is related to 1404 (2025) perspec- 
tive of Iran. Also there is a hard economical situation in Iran because of the sanctions and because of this complicated situation this methodology and research can be useful. There, moreover, was a new perspective in defining a game in game theory process and that was making a decision for a mixed strategy. There was a base strategy regarding normal situations. But the model has tried to make mix strategies that can enable competent decision makers to evaluate suppliers based on both stable and dynamic perspectives.

The study shows how this new framework can be effective in policy-makers' future decisions about critical issues when at least two different Nash Equilibriums exist.

\section{References}

Alimardani, M.; Hashemkhani Zolfani, S.; Aghdaie, M.; Tamosaitiene, J. 2013. A novel hybrid SWARA and VIKOR methodology for supplier selection in an agile environment, Technological and Economic Development of Economy 19(3): 533-548.

http://dx.doi.org/10.3846/20294913.2013.814606

Banerjee, N.; Biswas, S.; Chintada, S. 2006. A game-theoretic analysis of converged cellularvoip services, in IEEE 3rd Consumer Communications and Networking Conference, vol. 2, 8-10 January 2006. IEEE, Nevada, USA, 715-719.

Barfod, M. B.; Salling, K. B.; Leleur, S. 2011. Composite decision support by combining costbenefit and multi-criteria decision analysis, Decision Support Systems 51: 167-175.

http://dx.doi.org/10.1016/j.dss.2010.12.005

Bennett, P. G. 1980. Hypergames: the development of an approach to modeling conflicts, Futures 12: 489-507. http://dx.doi.org/10.1016/0016-3287(80)90005-1

Beske, P.; Land, A.; Seuring, S. 2014. Sustainable supply chain management practices and dynamic capabilities in the food industry: a critical analysis of the literature, International Journal of Production Economics 152: 131-143. http://dx.doi.org/10.1016/j.ijpe.2013.12.026

Binmore, K. 1994. Game theory. London: McGraw Hill.

Brams, S. J. 1994. Theory of moves. Cambridge, UK: Cambridge University Press.

Burguillo, J. C. 2010. Using game theory and competition-based learning to stimulate student motivation and performance, Computers \& Education 55: 566-575.

http://dx.doi.org/10.1016/j.compedu.2010.02.018

Camerer, C. F. 2003. Behavioral game theory: experiments in strategic interaction. Princeton: Princeton University Press.

Chang, C. L.; Hsu, C. H. 2009. Multi-criteria analysis via the VIKOR method for prioritizing land-use restraint strategies in the Tseng-Wen reservoir watershed, Journal of Environmental Management 90: 3226-3230. http://dx.doi.org/10.1016/j.jenvman.2009.04.020

Davis, M. D. 1997. Game theory: nanontechnical introduction. New York: Dover.

Dejus, T.; Antucheviciene, J. 2013. Assessment of health and safety solutions at a construction site, Journal of Civil Engineering and Management 19(5): 728-737.

http://dx.doi.org/10.3846/13923730.2013.812578

Fang, L.; Hipel, K. W.; Kilgour, D. M. 1993. Interactive decision making: the graph model for conflict resolution. New York, USA: Wiley.

Fraser, N. M.; Hipel, K. W. 1984. Conflict analysis: models and resolutions. North-Holland, Amsterdam, New York, USA: Wiley. 
Gibbons, R. 1991. A primer in game theory. Cambridge, MA, USA: MIT Press.

Hashemkhani Zolfani, S.; Bahrami, M. 2014. Investment prioritizing in high tech industries based on SWARA-COPRAS approach, Technological and Economic Development of Economy 20(3): 534-553. http://dx.doi.org/10.3846/20294913.2014.881435

Hashemkhani Zolfani, S.; Seyed Agha Banihashemi, S. 2014. Personnel selection based on a novel model of game theory and MCDM approaches, in 8th International Scientific Conference “Business and Management 2014”, 15-16 May 2014, Vilnius, Lithuania, 191-198.

Hashemkhani Zolfani, S.; Zavadskas, E. K.; Turskis, Z. 2013a. Design of products with both international and local perspectives based on Yin-Yang balance theory and SWARA method, Economska Istraživanja - Economic Research 26(2): 153-166.

Hashemkhani Zolfani, S.; Farrokhzad, M.; Turskis, Z. 2013b. Investigating on successful factors of online games based on explorer, E \& M: Ekonomie a Management 16(2): 161-169.

Hashemkhani Zolfani, S.; Aghdaie, M. H.; Derakhti, A.; Zavadskas, E. K.; Morshed Varzandeh, M. H. 2013c. Decision making on business issues with foresight perspective; an application of new hybrid MCDM model in shopping mall locating, Expert Systems with Applications 40: 7111-7121. http://dx.doi.org/10.1016/j.eswa.2013.06.040

Hashemkhani Zolfani, S.; Saparauskas, J. 2013. New application of SWARA method in prioritizing sustainability assessment indicators of energy system, Inzinerine Ekonomika - Engineering Economics 24(5): 408-414.

Hashemkhani Zolfani, S.; Zavadskas, E. K. 2013. Sustainable development of rural areas' building structures based on local climate, Procedia Engineering 57: 1295-1301.

Hennet, J. C.; Arda, Y. 2008. Supply chain coordination: a game-theory approach, Engineering Applications of Artificial Intelligence 21: 399-405. http://dx.doi.org/10.1016/j.proeng.2013.04.163

Howard, N. 1971. Paradoxes of rationality: theory of metagames and political behavior. Cambridge, MA, USA: MIT Press.

Howard, N. 1999. Confrontation analysis. CCRP Publications.

Hyde, K. M.; Maier, H. R. 2006. Distance-based and stochastic uncertainty analysis for multicriteria decision analysis in Excel using Visual Basic for applications, Environmental Modelling \& Software 21: 1695-1710. http://dx.doi.org/10.1016/j.envsoft.2005.08.004

Fiestras-Janeiro, M. G.; Garcia-Jurado, I.; Meca, A.; Mosquera, M. A. 2011. Cooperative game theory and inventory management, European Journal of Operational Research 210: 459-466. http://dx.doi.org/10.1016/j.ejor.2010.06.025

Iranian 1404 (2025). Perspective document 2010. [Online], [27 March 2013]. Available from Internet: http://edu1404.ir/fa/index.php?Page=definition\&UID=2765.

Kapliński, O.; Tamošaitienè, J. 2010. Game theory applications in construction engineering and management, Technological and Economic Development of Economy 16(2): 348-363.

http://dx.doi.org/10.3846/tede.2010.22

Keršulienè, V.; Turskis, Z. 2011. Integrated fuzzy multiple criteria decision making model for architect selection, Technological and Economic Development of Economy 17(4): 645-666.

http://dx.doi.org/10.3846/20294913.2011.635718

Keršulienè, V.; Zavadskas, E. K.; Turskis, Z. 2010. Selection of rational dispute resolution method by applying new step-wise weight assessment ratio analysis (SWARA), Journal of Business Economics and Management 11(2): 243-258. http://dx.doi.org/10.3846/jbem.2010.12

Kilgour, D. M. 1995. Book review: theory of moves, Group Decision and Negotiation 4: $283-$ 284. http://dx.doi.org/10.1007/BF01384693

Kilgour, D. M.; Hipel, K. W.; Fang, L. 1987. The graph model for conflicts, Automatica 23(1): 41-55. http://dx.doi.org/10.1016/0005-1098(87)90117-8 
Law, W. W.; Pan, S. Y. 2009. Game theory and educational policy: private education legislation in China, International Journal of Educational Development 29: 227-240.

http://dx.doi.org/10.1016/j.ijedudev.2008.04.003

Li, R.; Wang, F.; Wang, Y.; Liu, Y.; Li, Z. 2013. Game Optimization theory and application in distribution system expansion planning, including distributed generation, Energies 6: 1101-1124. http://dx.doi.org/10.3390/en6021101

Li, K. W.; Hipel, K. W.; Kilgour, D. M.; Fang, L. 2004. Preference uncertainty in the graph model for conflict resolution, IEEE Transactions on Systems, Man, and Cybernetics, Part A 34(4): 507-520.

Liou, J. J. H.; Tzeng, G. H. 2012. Comments on "Multiple criteria decision making (MCDM) methods in economics: an overview", Technological and Economic Development of Economy 18(4): 672-695. http://dx.doi.org/10.3846/20294913.2012.753489

Lootsma, F. A. 1999. Multi-criteria decision analysis via ratio and difference judgement. Dordrecht, The Netherlands: Kluwer Academic Publishers. http://dx.doi.org/10.1007/b102374

Madani, K. 2010. Game theory and water resources, Journal of Hydrology 381: 225-238. http://dx.doi.org/10.1016/j.jhydrol.2009.11.045

Meszek, W. 2001. Estimation of land plots using game theory, Technological and Economic Development of Economy 7(2): 62-68.

Meszek, W. 2004. Usage theory of the plays for the plot value inquiry, Technological and Economic Development of Economy 10(1): 40-46.

Meszek, W. 2007. Uncertainty phenomenon on property valuation, International Journal of Management and Decision Making 8(5-6): 575-585. http://dx.doi.org/10.1504/IJMDM.2007.013419

Meszek, W. 2013. Property valuation under uncertainty, simulation vs strategic model, International Journal of Strategic Property Management 17(1): 79-92. http://dx.doi.org/10.3846/1648 715X.2013.782165

Mohammadi Limaei, S. 2010. Mixed strategy game theory, application in forest industry, Forest Policy and Economics 12: 527-531. http://dx.doi.org/10.1016/j.forpol.2010.06.009

Moretti, S.; Vasilakos, A. V. 2010. An overview of recent applications of Game Theory to bioinformatics, Information Sciences 180: 4312-4322. http://dx.doi.org/10.1016/j.ins.2010.07.019

Mulliner, E.; Smallbone, K.; Maliene, V. 2013. An assessment of sustainable housing affordability using a multiple criteria decision making method, Omega 41: 270-279. http://dx.doi. org/10.1016/j.omega.2012.05.002

Nash, J. F. 1950. Equilibrium points in N-Person games, Proceedings of National Academy of Science of the USA 36: 48-49. http://dx.doi.org/10.1073/pnas.36.1.48

Nash, J. F. 1953. Two-person cooperative games, Econometrica 21: 128-140. http://dx.doi.org/10.2307/1906951

Nisan, N.; Roughgarden, T.; Tardos, E.; Vazirani, V. 2007. Algorithmic game theory. New York: Cambridge University Press. http://dx.doi.org/10.1017/CBO9780511800481

Peldschus, F. 2007. The effectiveness of assessments in multiple criteria decisions, International Journal of Management and Decision Making 8(5-6): 519-526.

http://dx.doi.org/10.1504/IJMDM.2007.013416

Peldschus, F. 2008. Experience of the game theory application in construction management, Technological and Economic Development of Economy 14(4): 531-545.

Peldschus, F.; Zavadskas, E. K. 2012. Equilibrium approaches for construction processes - multiobjective decision making for construction projects, Bauingenieur 87(5): 210-215. 
Postorino, M. N.; Praticò, F. G. 2012. An application of the Multi-Criteria Decision-Making analysis to a regional multi-airport system, Research in Transportation Business \& Management 4: 44-52. http://dx.doi.org/10.1016/j.rtbm.2012.06.015

Rego, L. C.; Halpern, C. Y. 2012. Generalized solution concepts in games with possibly unaware players, International Journal of Game Theory 41:131-155.

http://dx.doi.org/10.1007/s00182-011-0276-8

Reneke, J. A. 2009. A game theory formulation of decision making under conditions of uncertainty and risk, Nonlinear Analysis: Theory, Methods \& Applications 71:1239-46.

Sharma, R. S.; Bhattacharya, S. 2013. Knowledge dilemmas within organizations: resolutions from game theory, Knowledge-Based Systems 45: 100-113.

http://dx.doi.org/10.1016/j.knosys.2013.02.011

Soner Aplak, H.; Ziya Sogut, M. 2013. Game theory approach in decisional process of energy management for industrial sector, Energy Conversion and Management 74: 70-80.

http://dx.doi.org/10.1016/j.enconman.2013.03.027

Triantaphyllou, E. 2000. Multi-criteria decision making methods: a comparative study. Dordrecht: Kluwer Academic Publishers. http://dx.doi.org/10.1007/978-1-4757-3157-6

Von Neumann, J; Morgenstern, O. 1944. Theory of Games and economic behavior. Princeton: Princeton University Press.

Vafaeipour, M.; Hashemkhani Zolfani, S.; Morshed Varzandeh, M. H.; Derakhti, A.; Keshavarz, Eshkalag, M. 2014. Assessment of regions priority for implementation of solar plants in Iran: new application of a hybrid multi-criteria decision making approach, Energy Conversion and Management 86: 653-663. http://dx.doi.org/10.1016/j.enconman.2014.05.083

Vreeker, R.; Nijkamp, P.; Welle, C. T. 2002. A multicriteria decision support methodology for evaluating airport expansion plans, Transportation Research Part D: Transport and Environment 7(1): 27-47. http://dx.doi.org/10.1016/S0969-6997(01)00005-9

Wang, M.; Hipel, K.W.; Fraser, N. M. 1988. Modeling misperceptions in games, Behavioral Science 33(3): 207-223. http://dx.doi.org/10.1002/bs.3830330305

Zagorskas, J.; Turskis, Z. 2006. Multi-attribute model for estimation of retail centres influence on the city structure. Kaunas city case study, Technological and Economic Development of Economy 12(4): 347-352.

Zamarripa, M. A.; Aguirre, A. M.; Méndez, C. A.; Espuna, A. 2012. Improving supply chain planning in a competitive environment, Computers and Chemical Engineering 42: 178- 188. http://dx.doi.org/10.1016/j.compchemeng.2012.03.009

Zamarripa, M. A.; Aguirre, A. M.; Méndez, C. A.; Espuna, A. 2013. Mathematical programming and game theory optimization-based tool for supply chain planning in cooperative/competitive environments, Chemical Engineering Research and Design 91: 1588-1600.

Zavadskas, E. K.; Turskis, Z.; Antucheviciene, J.; Zakarevicius, A. 2012. Optimization of weighted aggregated sum product assessment, Elektronika ir Elektrotechnika (6): 3-6.

Zopounidis C. 1999. Multi-criteria decision aid in financial management, European Journal of Operational Research 119:404-15. http://dx.doi.org/10.1016/S0377-2217(99)00142-3 
Sarfaraz HASHEMKHANI ZOLFANI is PhD student of Technology Foresight in Amirkabir University of Technology (Tehran Polytechnic). He is working at Futures Studies Research Institute of Amirkabir University of Technology (Tehran Polytechnic), Sustainability office of Amirkabir University of Technology (Tehran Polytechnic) and Research Institute of the Internet and Intelligent Technologies, Vilnius Gediminas Technical University. He is member of EURO Working Group OR in Sustainable Development and Civil Engineering. He is reviewer in journals like: International Journal of Strategic Property Management, International Journal of Environmental Research, Journal of Applied Mathematics and etc. He is author of more than 50 scientific papers that presented, published or reviewed at/for International Conferences and Journals (including ISI-cited publications). He has published in journals such as: Expert Systems With Applications, Energy Conversion and Management, Technological and Economic Development of Economy, Journal of Business Economics and Management, International Journal of Strategic Property Management, Archives of Civil and Mechanical Engineering, Transport, The Baltic Journal of Road and Bridge Engineering and etc. His research interests include: Performance Evaluation, Strategic Management, Decision-making Theory, Supply Chain Management, (Dynamic) Multi Criteria Decision Making, Future Studies, Sustainable Development and Game Theory.

Reza MAKNOON is faculty member of Civil and Environmental Engineering Department of Amirkabir University of Technology (Tehran Polytechnic) since 1977. He got PhD in Environmental Engineering from University of Washington in 1977. He is president of Iranian Water Resource Association and ex-president of Society for Science Development in Iran and also vice president of Iranian Society of Environmentalists. He is member and past president of Iranian National Committee on Hydrology (IHP) and also Iranian Committee on Large Dams. He is chairperson of Iranian National Committee for Sustainable Development (CSD) since 1995 in Iran. He is author of more than 70 research articles in sustainable tourism, water resource developments, environmental impact assessments, research policies and human development and higher education fields. He is editorial board of Environmental Studies (Quarterly Journal) of Iran.

Edmundas Kazimieras ZAVADSKAS. PhD, DSc, h.c.multi. Prof., the Head of the Department of Construction Technology and Management at Vilnius Gediminas Technical University, Lithuania. Senior Research Fellow at the Research Institute of Smart Building Technologies. PhD in Building Structures (1973). DrSc in Building Technology and Management (1987). A member of Lithuanian and several foreign Academies of Sciences. Doctore Honoris Causa from Poznan, Saint Petersburg and Kiev universities. Honorary International Chair Professor of the National Taipei University of Technology. A member of international organizations; a member of steering and programme committees at many international conferences; a member of the editorial boards of several research journals; the author and co-author of more than 400 papers and a number of monographs in Lithuanian, English, German and Russian. The editor-in-chief of journals Technological and Economic Development of Economy and Journal of Civil Engineering and Management. Research interests: building technology and management, decision-making theory, automation in design and decision support systems. 